DUKE B.O.L. : Observations on Onchocerca volvulus in experimentally infected chimpanzees. Tropenmed. Parasitol., 1980, 31, 4154.

Eberhard M.L., Orihel T.C. : Loa loa : output of microfilariae in single pair infections. Trop. Med. Parasitol., 1986, 37, 369-374.

HAWkING F. : The reproductive system of Litomosoides carinii, a filarial parasite of the cotton rat. III. The number of microfilariae produced. Ann. Trop. Med. Parasitol., 1954, 48, 382-385.

Karam M., Schulz-Key H., Remme J. : Population dynamics of Onchocerca volvulus after 7 to 8 years of vector control in West Africa. Acta Tropica, 1987, 44, 445-457.

Mössinger J., Wenk P. : Fecundity of Litomosoides carinii (Nematoda, Filaroidea) in vivo and in vitro. Z. Parasitenk., 1986, 72, 121-131

MÖssinger J., Barthold E. : Fecundity and localization of Dipetalonema viteae (Nematoda, Filarioidea) in the jird Meriones unguiculatus. Parasitol. Res., 1988, 74, 84-87.

Plaisier A.P., van Oortmarssen G.J., Remme J., Habbema J.D.F. : The reproductive lifespan of Onchocerca volvulus in West African savanna. Acta Tropica, 1991, 48, 271-284.

SCHULZ-KeY H. : Observations on the reproductivity of Onchocerca volvulus. Third Int. Symp. of Invertebrate Reproduction. Tübingen, 1983, 2-27 August.

Schulz-Key H. : The collagenase technique : how to isolate and examine adult Onchocerca volvulus for the evaluation of drug effects. Trop. Med. Parasitol., 1988, 39, 423-444.

SCHULZ-KeY H. : Observation on the reproductive biology of Onchocerca volvulus. Acta Leidensia, 1990, 59, 27-43.

Schulz-Key H., Karam M. : Periodic reproduction of Onchocerca volvulus. Parasitol. Today, 1986, 2, 284-286.

Schulz-Key H., Karam M. Mössinger J., Remme J. : The worm population of Onchocerca volvulus 10 years after vector control in West Africa. Zbl. Bakt. Hyg, 1987, 265, 492

Soboslay P.T., Dreweck C.M., Taylor H.R., Brotman B., Wenk P. GREENE B.M. : Experimental onchocerciasis in chimpanzees. Cellmediated immune response, and production and effects of IL-1 and IL-2 with Onchocerca volvulus infection. J. Immunol., 1991, 147, 346-353.

Trees A.J., WAHL G., Kl.̈̈ger S., Renz A. : Age-related differences in parasitosis may indicate acquired immunity against microfilariae in cattle naturally infected with Onchocerca ochengi. Trop. Med. Parasitol., 1992, 104, 247-252.

VANKan D.M., Copeman D.B. : Reproduction of female Onchocerca gibsoni. Trop. Med. Parasitol., 1988, 39, 469-471.

Weinstein P.P., SAwYer T.K. : Survival of adult Dirofilaria uniformis in vitro and their production of microfilariae. J. Parasitol., 1961, $76,23-24$

\section{ISOLATION OF NEW MARKERS TO DETECT GENETIC VARIATION IN ONCHOCERCA VOLVULUS} HERDER S.*, BELLEC CH.* AND CUNY G.**

KEYWORDS : Onchocerca volvulus. genetic variability. RAPD. microsatellite. PCR.

SUMMARY

Newly developed techniques (RADP : Random Amplified Polymorphic DNA and microsatellite DNA sequences) were used to study genetic

\footnotetext{
* Laboratoire d'Epidémiologie de Maladies à Vecteurs, Centre ORS TOM de Montpellier, 911 av. Agropolis, BP 5045, 34032 Montpellier, France.

*** Laboratoire Rétrovirus-Parasites, Centre ORSTOM de Montpellier, 911 av. Agropolis, BP 5045, 34032 Montpellier, France.
}

variation in Onchocerca volvulus. RAPD technique, derived from the Polymerase Chain Reaction (PCR), allow clear distinction between the different species of the genus Onchocerca.

Microsatellite DNA has been shown to be useful as polymorphic markers for populations and even for individuals. Short repeated sequences (CA repeats) have been isolated, and a PCR assay using such microsatellite DNA sequences to generate polymorphisms is currently being experimented.

$\mathrm{n}$ West Africa, particularly in the OCP area (Onchocerciasis Control Programme), at least two strains of the parasite are known to exist. The so-called "savannah" strain associated with high blindness level, and the "forest" strain associated with a milder form of onchocerciasis which causes blindness in less than $1 \%$ of the population (Prost et al., 1980). However, Sierra Leone is exceptional in that high levels of blindness are found in forest areas (McMahon et al., 1986).

Various Onchocerca specific DNA probes have been developed (Meredith et al., 1989) and also strain specific probes (Erttmann et al., 1987 and 1990). These DNA probes sequences are based on the 150 bp repeat family. Recently, studies conducted in West Africa have shown that DNA probe classification correlates with the epidemiology of blindness (Zimmerman et al., 1992).

In Cameroon, the situation is more complex, notably the pathology of blindness is distributed without apparent relation to bioclimatic zones (Duke, 1981 ; Boussinesq et al., 1993). To date, no studies similar to those carried out in West Africa have been done in Cameroon.

We are investigating other molecular markers that may be useful for studies on genetic variation in O. volvulus, namely RAPD and microsatellite sequences.

Polymorphism in genomic fingerprints generated by Random Amplified Polymorphic DNA (RAPD) is a recently developed assay that is based on the amplification by the Polymerase Chain Reaction (PCR) of random DNA fragments. In RAPD mapping, decamer oligonucleotide primers of arbitrary sequence but with a GC content of $50 \%$ or higher are used to amplify fragments of genomic DNA (Williams et al., 1990 ; Welsh and McClelland, 1990).

RAPD has been successfully applied to the analysis of genomic DNA variation of several organisms (Williams et al., 1990 ; Hadrys et al., 1992 ; Klein-Lankhorst et al., 1991 ; Crowhurst et al., 1991 ; Mazurier et al., 1992). Strains can be distinguished by comparing polymorphisms in genomic fingerprints (Welsh et al., 1991).

The particular advantages of RAPD technology is that small amounts (nanograms) of genomic DNA are needed and, unlike PCR, no prior sequence knowledge is needed.

Microsatellite DNA sequences are short (from 2 to $5 \mathrm{bp}$ ), tandemly repeated sequences that have been shown to be useful as polymorphic markers for populations and even for individuals. They have been reported from a large panel of eukaryotic species such as human, mouse, cattle, whales and insects (Tautz, 1989 ; Love et al., 1990 ; Swaiger et al., 1992 ; Weber and May, 1989 ; Hughes and Queller, 1993). These dinucleotide repeats are referred to as microsatellites (Litt and Luty, 1989). Most of these regions are less than $200 \mathrm{bp}$ in length and PCR is used to detect length polymorphisms.

We describe here the use of the RAPD assay for the detection of variation in the genus Onchocerca, using a set of 20 
oligonucleotide decamer primers and the adaptation of microsatellite DNA sequences to study genetic variability in O. volvulus populations.

\section{METHODS}

\section{RAPD}

\begin{abstract}
Todules containing O. volvulus were excised and collage1 nase-digested (Schulz-Key et al., 1977) and the worms preserved in absolute alcohol. The nodules were from savannah and degraded forest areas of Cameroon (Touboro, Poli and Bafia, Sa'a) and from forest regions of Sierra Leone (Lunsar and Njala).

O. gutturosa, O. lienalis, O. gibsoni and O. ochengi DNA was provided by Dr. Meredith. O. volvulus DNA was extracted from worms as described by Meredith et al. (1991). PCR reactions were performed in $25 \mu$ l of $10 \mathrm{mM}$ Tris-HC1 $(\mathrm{pH}$ 9.0), $50 \mathrm{mM} \mathrm{KCl}, 0.1 \%$ Triton X-100, $1.5 \mathrm{mM} \mathrm{MgCl}_{2}, 0.2$ $\mathrm{mM}$ of each dNTP, 20 picomoles of decamer primer(s) (Operon Technologies Inc.), 25 ng template DNA and 1 unit Taq polymerase (Promega). Amplification was carried out in a thermocycler (Techne PHC-3) programmed for 45 cycles of 1 minute at $92^{\circ} \mathrm{C}, 1$ minute at $36^{\circ} \mathrm{C}$ and 2 minutes at $72^{\circ} \mathrm{C}$. Amplification products were resolved electrophoretically on $1.4 \%$ agarose gel.
\end{abstract}

\section{Microsatellite DNA SEQuences}

Nodules containing O. volvulus worms from 14 patients originating from 4 different foci in Cameroon were excised and collagenase digested in the field. Total genomic DNA from the worms was digested to completion with the restriction enzymes HaeIII, AluI, TaqI, Hinfl and SaußA and shotgun cloned under standard conditions into a M13BM20 vector containing an EcoRV site (Hanahan, 1983). Poly $(\mathrm{CA})_{\mathrm{n}} /(\mathrm{GT})_{\mathrm{n}}$ and poly $(\mathrm{GA})_{\mathrm{n}} /(\mathrm{CT})_{\mathrm{n}}$ probes for detection of respectively $(\mathrm{CA})_{\mathrm{n}} /(\mathrm{GT})_{\mathrm{n}}$ and $(\mathrm{GA})_{\mathrm{n}} /(\mathrm{CT})_{\mathrm{n}}$ microsatellites sequences were labelled by random priming in the presence of $[\alpha$ 32P]dCTP (Feinberg and Vogelstein, 1983). The genomic M13 library was screened by transfering the plaques onto nylon membranes. Prehybridization and hybridization were performed at $65^{\circ} \mathrm{C}$ in a solution containing $0.5 \%$ nonfat powdered milk, $5 \mathrm{X}$ SSPE, $1 \%$ SDS, $100 \mu \mathrm{g} / \mathrm{ml}$ denatured salmon sperm DNA, followed by two washes of 15 minutes each in $2 \mathrm{X}$ SSPE, $0.1 \%$ SDS, one of 15 minutes in $0.5 \mathrm{X}$ SSPE, $0.1 \%$ SDS and the stringent wash of 15 minutes in 0.1 $\mathrm{X}$ SSPE, $0.1 \%$ SDS at $65^{\circ} \mathrm{C}$. Dried filters were then autoradiographed with an intensifying screen on Hyperfilm (Amersham) at $-70^{\circ} \mathrm{C}$ for 2 to 16 hours. Single-stranded template DNA was isolated from positive plaques (Messing, 1983) and sequenced (Sanger, 1977) on an automatic sequencer (Applied Biosystems, Inc.).

PCR primers were chosen from the region immediatly flanking the microsatellite sequence. These primers were designed with computer assistance to minimize self annealing. PCR conditions were optimized by combining different $\mathrm{Mg}^{2+}$ concentrations, annealing temperatures and number of amplification cycles. PCR products were resolved on non-denaturing acrylamide gels (from 7 to $10 \%$ ) and visualised by ethidium bromide $(1 \mathrm{mg} / \mathrm{ml})$ or silver staining
(0.2\% silver nitrate for 30 minutes and reduction with $0.75 \mathrm{M} \mathrm{NaOH} ; 0.1 \mathrm{M}$ formaldehyde for 10 minutes).

\section{RESULTS AND DISCUSSION}

irst, we investigated the potential of RAPD in differentiating at the species level. Genomic DNA from different species was amplified by use of a single decamer primer, 20 primers were tested in these experiments and in each case, at least one specific fragment was obtained for the Onchocerca DNA's used. For each sample, some of the bands (ranging from $1.5 \mathrm{~Kb}$ and $150 \mathrm{bp}$ ) are common for the genus Oncbocerca and some are unique to one species depending on the primer used. By comparing fingerprints generated by the RAPD method, Onchocerca volvulus, $O$. gutturosa, O. lienalis, O. gibsoni and O. ochengi can be identified and distinguished from each other by the specific polymorphic patterns.

Secondly, RAPD profiles of different O. volvulus isolates have been compared using the same primer as described earlier. Different patterns are observed between different isolates and even between worms from the same nodule.

Using these primers, we could observe differences between species and also between O. volvulus isolates. However when amplification is repeated, we often find the profiles to vary slightly. Furthermore, the presence of DNA contamination can seriously affect the results. Thus, in this case, this technique seems more suitable for isolation of new DNA probes rather than for studies on population genetic.

Microsatellite loci can be easily scored using polymerase chain reaction (PCR) followed by electrophoresis to separate alleles which differ in length as a result of differences in the number of repeat units. The microsatellite sequences isolated from $O$. volvulus have been used to make primers (microsatellite flanking regions) to identify different strains of the parasite. These particular sequences consist of CA repeats. Initial results using $O$. volvulus microsatellite primers shows only slight differences between isolates. This lack of resolution observed between bands representing alleles (in some cases separated only by 2 bp) can be explained by the use of non denaturing acrylamide gel to visualize amplification products. In order to allow better resolution of DNA fragments, this technique can be improved by using denaturing sequence acrylamide gels.

In conclusion, we believe that these new tools developed (particularly microsatellites) will be useful for investigating the genetic variation in $O$. volvulus.

\section{ACKNOWLEDGEMENTS}

e are very grateful to Dr. M. Boussinesq and Dr. J.P. Chippaux for providing us with material and epidemiological data. We also thanks Dr. J.P. Aussel for excellent technical assistance.

\section{REFERENCES}

Boussinesq M., Chippaux J.P. and Pron'hon J. : Rapid assessment of onchocerciasis endemicity in Cameroon : a study in savanna and in forest - savanna mosaic. Joint Meeting- of the American Society of parasitologists and the American Society of Tropical Medicine and Hygiene, Atlanta, Georgia, 1993, 31 Oct.-4 Nov. 
Crowhurst R.N., Hawthorne B.T., RikKerink E.H. and Templeton M.D. : Differentiation of Fusarium solani f. sp. cucurbitae races 1 and 2 by random amplification of polymorphic DNA. Current Genet., 1991, 20, 391-396.

DukE B.O.L. : Geographical aspects of onchocerciasis. Ann. Soc. Belge Med. Trop., 1981, 61, 179-186.

Erttmann K.D., Unnasch T.R., Greene B.M., Albiez E.J., Boateng J., Denke A.M., Ferraroni J.J., Karam M., Schulz-Key H. and Williams P.N. : A DNA sequence specific for forest form Onchocerca volvulus. Nature, 1987, 327, 415-417.

Erttmann K.D., Meredith S.E.O., Greene B.M. and Unnasch T.R. Isolation and characterisation of form specific DNA sequences of O. volvulus. Acta Leidensia, 1990, 1-2, 253-260.

Feinberg A.P. and Volgeistern B. : A technique for radio labelling DNA restriction endonucleases fragments to high specific activity. Anal. Biochem., 1983, 137, 6-13.

Hadrys H., Balick M. and Schierwater B. : Applications of random amplified polymorphic DNA (RAPD) in molecular ecology. Mol. Ecol., 1992, 1, 55-63.

Hanahan D. : Studies on transformation of Escherichia coli with plasmids. J. Mol. Biol., 1983, 166, 557-580

Hugues C.R. and Quelier D.C. : Detection of highly polymorphic microsatellite loci in a species with little allozyme polymorphism. Mol. Ecol., 1993, 2, 131-137.

Klein-Lankhorst R.M., Vermunt A., Weide R., Liharska T. and Zabel P. : Isolation of molecular markers for tomato (L. esculentum) using random amplified polymorphic DNA (RAPD). Theor. Appl. Genet., 1991, 83, 108-114.

LITT M. and LuTY J.A. : A hypervariable microsatellite revealed by in vitro amplification of a dinucleotide repeat within the cardiac muscle actin gene. Am.J. Hum. Genet., 1989, 44, 397-401.

Love J.M., Knight A.M., McAleer M.A. and Todd J.A. : Towards construction of a high resolution map of the mouse genome using PCR-analysed microsatellites. Nucl. Ac. Res., 1990, 18, $n^{\circ} 14,4123-4130$

Mazurier S., van de Giessen A., Heuvelman K. and Wernars K. : RAPD analysis of Campylobacter isolates : DNA fingerprinting without the need to purify DNA. Letters in Appl. Microbiol., 1992, 14, 260-262.

McMahon J.E., Davies J.B., White M.D., Goddard J.M., BeechGaRwoOd P.A. and KIRKWOOD B.R. : Onchocerciasis in Sierra Leone. I. Studies on the prevalence and transmission at Gbaiima village. Trans. Roy. Soc. Trop. Med. Hyg., 1986, 80, 802-809.

Meredith S.E.O., Unnasch T.R., Karam M., Piessens W.F. and Wirth D.F. : Cloning and characterisation of an Onchocerca volvulus specific DNA sequence. Mol. Biochem. Parasitol., 1989, 36, 1-10.

Meredith S.E.O., Lando G., Gbakima A.A., Zimmerman P.A. and UNNASCH T.R. : Onchocerca volvulus : application of polymerase chain reaction to identification and strain differentiation of the parasite. Exp. Parasitol., 1991, 73, 335-344.

Messing J. : New M13 vectors for cloning. In Methods in Enzymology. Wu R., Grossman L. and Moldave K. (eds), New York, Academic Press, 1983, vol. 101, 10-89.

Prost A., Rougemont A. and Omar M.S. : Caractères épidémiologiques, cliniques et biologiques des onchocercoses de savane et de forêt en Afrique occidentale. Ann. Parasitol., 1980, 55, $347-$ 355 .

SAnger F., Nicklen S. and Coulson A.R. : DNA sequencing with chain-terminating inhibitors. Proc. Natl. Acad. Sci., 1977, 74, 5463-5467.

Schulz-Key H., Albiez E.J., Buttner D.W. : Isolation of living adult Onchocerca volvulus from nodules. Tropenmed. Parasitol., 1977, 28, 428-430.

Swaiger F.W., Gomolka M., Geldermann H., Zischler H., Buttkamp J., Epplen J.T. and Ammer H. : Oligonucleotide fingerprinting to individualize ungulates. Appl. Theor. Electrophoresis, 1992, 2, 193 200

TAuTz D. : Hypervariability of simple sequences as a general source for polymorphic DNA markers. Nucl. Ac. Res., 1989, 17, $\mathrm{n}^{\circ} 16$, 6463-6471.

WEBER J.L. and MAY P.E. : Abundant class of human DNA polymorphisms which can be typed using the polymerase chain reaction. Am.J. Hum. Genet., 1989, 44, 388-396.

Welsh J. and Mc Clelland M. : Fingerprinting genomes using PCR with arbitrary primers. Nucl. Ac. Res., 1990, 18, n 24, 7213-7218.

Welsh J., Petersen C. and Mc Clelland M. : Polymorphisms generated by arbitrarily primed PCR in the mouse : application to strain identification and genetic mapping. Nucl. Ac. Res., 1991, 19, $n^{\circ} 2,303-306$

Williams J.G.K., Kubelik A.R., Livak K.J., Rafalski J.A. and Tingey S.V. : DNA polymorphisms amplified by arbitrary primers are useful as genetic markers. Nucl. Ac. Res., 1990, 19, $\mathrm{n}^{\circ}$ 2, 303-306.

Zimmerman P.A., Dadzie K.Y., de Sole G., Remme J., Soumbey Alley E. and UnNasch T.R. : Onchocerca volvulus DNA probe classification correlates with epidemiologic patterns of blindness. J. Inf. Diseases, 1992, 165, 964-968.

\section{CUTICLIN GENES OF NEMATODES}

LEWIS E.*, SEBASTIANO M.*, NOLA M.*, ZEI F.*, LASSANDRO

F. ${ }^{*}$, RISTORATORE F., ${ }^{*}$ CERMOLA M. ${ }^{*}$, FAVRE R.* AND

BAZZICALUPO P*

KEYWORDS : parasitic nematodes, cuticle. cuticlin. dityrosine. cross-linking.

SUMMARY

Two genes coding for cuticlin components of Caenorhabditis elegans have been cloned and their structure is described. Recombinant proteins have been produced in E. coli and antibodies raised against them. Nucleic acid and specific antibodies are being used to isolate the homologues from the parasitic species Ascaris lumbricoides and Brugia pahangi.

he nematode cuticle protects the animal, serves as an exoskeleton and provides the surface over which interactions with the external environment occur. In the case of parasitic nematodes the external environment is the host and, as such, antigens expressed on/in the cuticle are within reach of both the humoral and cellular components of the immune system. The cuticle is a layered structure, the components of which are classified according to their solubility : lipids, some proteins and other readily soluble, non-structural components are mostly localized on the surface but are also distributed to a lesser extent throughout the lower layers of the cuticle; the collagens make up the structural bulk of the cuticle, are coded for by a large and relatively well-characterized gene family, are not exposed on the cuticle surface and can be solubilized with SDS and mercaptoethanol ; and finally there is a highly cross-linked, insoluble and complex mixture of proteins present throughout the cuticle and known as the cuticlins. Up until now it has been virtually impossible to determine the roles and importance of the cuticlins because their insolubility does not allow either molecular or biochemical analysis of individual proteins.

* International Institute of Genetics and Biophysics, CNR, via G Marconi 10, 80125 Napoli, Italy. 